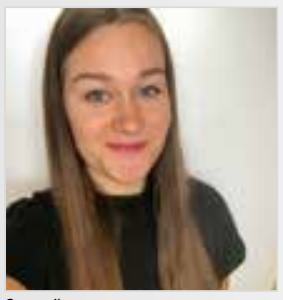

Szerző:

\section{FARAGÓ DIÁNA}

PTETTK Sporttudományi és Testnevelési Intézet, sportszervező szak dianafarago2@gmail.com

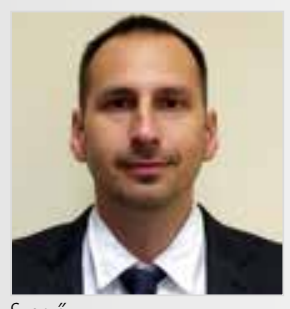

Szerzo":

PAIC RÓBERT

PTE Természettudományi Kar Sporttudományi és Testnevelési Intézet Kutatási területei: sportpszichológia, sportmotiváció

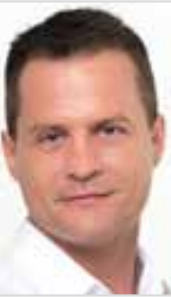

Szerzo:

DR. HABIL. FRITZ PÉTER egyetemi docens Ferencvárosi Torna Club, Miskolci Egyetem pritz@hotmail.hu Tudományos tevékenysége: doktori iskolában témavezetô Főbb kutatási terület: sporttáplálkozás, rekreáció

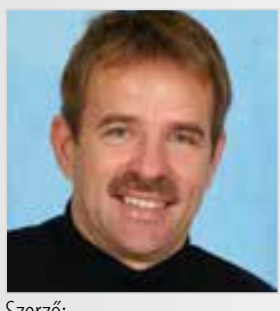

DR. HABIL. NÉMETH ZSOLT habilitált egyetemi docens 7634 Pécs, Gém utca 34 Főbb kutatási területei: neveléstudomány, sporttudomány, sportpedagógia, sportpszichológi zsolt.nemeth@gamma.ttk.pte.hu

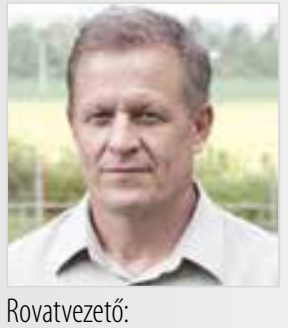

DR. SZATMÁRI ZOLTÁN

föiskolai tanár

thend.2011@gmail.com

KERT, Tehetséggondozás programvezető
A kutatásunk témájául azért választottuk a felnőttkori korcsolyázás motivációját, mert kiskoromtól kezdve a korcsolyázás a mindennapjaim része. A versenyzés befejeztével, edzőként kezdtem el tevékenykedni, amelynek során különböző korosztályokkal dolgoztam együtt. Azonban a felnőttek voltak azok, akik a leginkább kíváncsiságot ébresztettek bennem, és leggyorsabban egy hullámhosszra tudtam velük kerülni. A kutatás alanyai azok a 18 éves és afeletti felnőttek voltak, akik tanfolyami szinten korcsolyáznak, illetve azok, akik versenyzőként kerültek kapcsolatba a korcsolyázással.

A kutatással elsősorban az volt a célunk, hogy megvizsgáljuk, mi motiválja felnőttként az embereket a rendszeres korcsolyázásra, ezenkívül néhány kérdés erejéig a felek között kialakuló konfliktushelyzetekre is kitértünk. Kutatásunkban az egész ország területén működő egyesületek versenyzőit és tanfolyami résztvevőit kérdeztük meg egy saját szerkesztésű kérdőívben. A kérdőív 46 kérdést tartalmazott, melyben szerepeltek nyitott és zárt kérdések; Likert-skála; egy vagy több válaszlehetőséget megjelölendő; illetve saját választ leírandó kérdések is. A kérdések nagy része sportággal kapcsolatos volt, emellett demográfiai kérdések is megjelentek.

\section{- abstract:}

We chose the motivation of adult skating of our research because the skating was the part of my everyday since I was child. When I finished the racing, I started working as a coach, and I worked with different ages. However, it was the adults who aroused the most curiosity in me, and I was able to identify with them the fastest. The subjects of the research were adults 18 years of age and older who skated at course and those who came into contact with skating as a competitor. The main purpose of the research was to examine what motivates people to skate regularly as adults, and we also covered the conflict situations between the parties to the extent of some questions. In our research, we interviewed competitors and course participants from associations across the country in a self-edited questionnaire. The questionnaire contained 46 questions with open-ended and closed-ended questions; Likert scale; indicate one or more possible answers; and questions to describe your own answer. Most of the questions were related to sports, but demographic questions also emerged. All in all, responses were received from 104 people, and after

\section{BEVEZTÉE}

A felnőttkori korcsolyázás motivációját azért választottuk kutatásunk témájaként, mert gyermekkoromtól kezdve szinkronkorcsolyáztam. Ez a sportág végigkísért egészen a felnőtté válásomig. Versenyszerűen már nem korcsolyázom, szerencsére a sors úgy hozta, hogy edzőként segédkezni tudok az egyesületnél, ahol nevelkedtem.

Az egyesület versenyzőkkel és amatőr korcsolyázókkal is foglalkozik. Nagyjából 10-15 éve jelent meg tanfolyami oktatás keretében a felnőttoktatás, azóta egyre népszerúbb, és versenycsapat is alakult a lelkes résztvevőkből. Ök többnyire felnőttként tanultak meg
Összesen 104 főtől érkeztek be válaszok, és ezek kiértékelése után összehasonlítottuk a két csoportot, vagyis a versenyzők és a tanfolyami résztvevők véleményét. Ezeket az eredményeket Excel-táblázatban átkódoltuk majd SPSS rendszert alkalmaztunk a különböző kimutatásokhoz. A kitöltésben 91 fő nő és 13 fő férfi vett részt. Legtöbben 40-49 év közöttiek voltak a kitöltők, a legidősebb kitöltő pedig 66 éves volt. A legtöbb kitöltőnek konfliktushelyzetben nem volt része, ők 66 főt jelentettek. A kutatás eredménye az lett, hogy az 5 hipotézisünkből 4 beigazolódott, és 1 nem. Eszerint nem igazolódott be az, hogy a felnőttek minden esetben gyermekeik miatt kezdenek el korcsolyázni.

Beigazolódott, hogy esés vagy rossz tapasztalat nagyban befolyásolja azt, hogy folytatják-e a korcsolyázást. A versenyzőket ezek egyáltalán nem befolyásolják. Beigazolódott, hogy edzéseken nem tartják fontosnak a résztvevők, hogy mindig újat tanuljanak, de ha mégis új elem vagy korcsolyalépés tanulására kerül sor, azt élvezettel veszik. Az is beigazolódott, hogy a versenyzők több pénzt költenek a korcsolyázásra, mint tanfolyami társaik. Szintén beigazolódott, hogy a versenyzőket és a tanfolyami résztvevőket pedig teljesen más motiválja a korcsolyázásban.

Kulcsszavak: korcsolyázás, motiváció, felnőttkor

evaluating them, we compared the opinions of the two groups: the competitors and the course participants. we transcoded these results in an Excel spreadsheet and then applied SPSS to the different statements. 91 women and 13 men participated in the completion. Most of the respondents were aged 40-49, and the oldest respondent was 66 years old. Most respondents did not have a conflict situation, they reported 66 people. The result of the research was that 4 of our 5 hypotheses were confirmed and 1 was not. According to this, it has not been proven that adults always start skating because of their children. It has been shown that a fall or a bad experience greatly influences whether to continue skating. Competitors are not affected at all. It has also been proven that in training sessions, participants do not consider it important to always learn something new, but if they do learn a new element or skate move, they take it with pleasure. It has also been proven that competitors spend more money on skating than their course participants. It has also been proven that competitors and course participants are motivated to skate in a completely different way.

Keywords: skating, motivation, adulthood korcsolyázni, és lettek szerelmesei a sportágnak. Ez az úgynevezett „Adult” csapat évente nagyjából 2-3 versenyen vesz részt. A versenyekre történő nevezés a lelkesedésüktől, a versenyhelyszínektől és költségektől függnek főként. Sajnos nagyon kevés pénzbeli támogatást kap ez a sportág, így mindent a versenyzőnek kell finanszírozniuk.

Emiatt, sajnálatos módon nem mindenki teheti meg, hogy a versenycsapat tagja legyen a család mellett. Edzőként kicsiktől a nagyokig, minden korosztállyal foglalkoztam már, de különösképpen a felnőttek keltették fel az érdeklődésemet: a lelkesedésük, hogy többnyire minden edzésen részt vesznek, időt, pénzt és energiát fektetnek bele, hogy eljárjanak sportolni. Mindezt az időt 
legtöbbször a családtól veszik el. Leginkább arra voltunk kíváncsiak velük kapcsolatban, hogy mi motiválja ooket a korcsolyázásra, hiszen nem egy egész évben űzhető sportágról van szó. Ráadásul a szezon nagyobb részében nagyon hideg van a jégcsarnokban, az edzések időpontjai pedig hétköznap késő este, vagy hétvégén kora reggeli órákban vannak, amikor a jégcsarnokban a leghidegebb van.

\section{SZAKIRODALMI ÁTTEKINTÉS}

Szakirodalmi áttekintésünkben a teljesség igénye nélkül a sport és motiváció kapcsolatát vizsgáltuk. A motivációnak kétféle forrása lehet: az egyik a külső, vagyis extrinzik, a másik pedig a belső, vagyis intrinzik tényezők. Belső motiváció lehet, amikor egy sportoló a saját öröme és megelégedettsége miatt úzi az adott sportot (Ryan és Deci, 20ooa; Rayan és Deci, 200ob). Kun és Vincze tanulmányából kiderül, hogy a sportban az alábbi motiváló tényezők jelennek meg: mozgás szeretete, kezdeti sikerek, ideálkövetés, családi példamutatás, elismerésigény és a médiahatások (Kun és Vincze, 2016). Mivel sportolókról beszélünk, a viszszajelzést nagyon fontosnak tartjuk edzői és tanítványi oldalról egyaránt. Ezt alá is támasztja Gyömbér és Kovács: „A sportban a visszajelzés már a teljesítmény közben vagy azt követően szinte azonnal megjelenik. Siker után kellemes és pozitív érzéseket élünk meg, ezzel szemben a kudarcot követően többnyire a hangulatunk is nyomott." (Gyömbér és Kovács, 2012)

Szemes, Harsányi és Tóth egy 7 faktoros sportmotivációs kérdőív segítségével a flowélményt mérték, amelyból az derült ki, hogy a sportmotiváció tekintetében a küzdősportokat végzők a leginkább belső motiváltak, ezzel szemben a flowélmény a legkevésbé a múvészi sportoknál jelenik meg (Szemes, Harsányi és Tóth, 2016).

Mindezeket összevetve elmondható, hogy ezek a tényezők nagyon sok mindentől függnek. Legjobban Bíróné foglalta össze: „A jó adottságok önmagukban nem jelentenek garanciát a kiemelkedő teljesítmény és eredmények eléréséhez. Ezekhez megfelelő elszántság, stabil motivációs bázis, jól felépített és fáradságos edzésmunka, valamint kedvező külső környezeti feltételek szükségesek." (Bíróné, 2011)

Kun és Vincze kutatásukban azt részletezik, hogy a kognitív értelmezés az önjutalmazó motivációt erősíti. Az ismeretszerző magatartáshoz szükséges, hogy jelen legyen a kíváncsiság motívuma, amely az egyént az új dolgok megismerése felé hajtja. Azok mellett, hogy külső és belső motivációs tényezők fontosak, felnőttkorban is nagy szerepe van az edzői dicséretnek. Ez az áramlatélmény átéléséhez is hozzájárul (Kun és Vincze, 2016). Horvát kutatók végeztek felnőttek körében sportmotivációs vizsgálatot, amiből az derült ki, hogy nincs szignifikáns különbség az érmeket nyerô versenyzők és azok között, hogy valaki nyugdíjas, vagy idős kora ellenére még mindig aktív.
Nagy a „Sport iránti érdeklődést kiváltó okok" közé a következőket sorolta (Nagy, 1973):

1. Különböző személyek - szülők, tanárok, barátok, testvérek, sportoló ismerősök stb. - hatása.

2. Anyagi tényezők (anyagi előnyök, kereseti lehetőségek, utazási lehetőségek $s t b$.$) .$

3. Gyakorlatok, versenyek, edzések hatása (pl. imponálási vágy, hírnév, dicsőség szerzése, eredmények elérése, megszokás, szenvedély, győzelemvágy stb.).

4. A sporttal való foglalkozás feltételeinek szerepe (pl. sporteszközök birtoklása, természetes feltételek megléte stb.).

5. Egészségügyi tényezők ( $p l$. erőnlét fejlesztése, kellemes külső megjelenés biztositása, a helyes testi fejlődés elösegítése stb.).

6. Propaganda és nevelési tényezők ( $p l$. sportversenyek látogatása, rádió- és televízióközvetítések stb.).

7. Általános jellegű tényezók (pl. érdeklődés, a sport szeretete, mozgásigény kielégítése stb.). (Nagy, 1973)

Paic véleménye szerint fontos a megfeleló motivációs környezet kialakítása:

„A motivációs légkört az határozza meg, amit az edző csinál és mond, és ahogyan a környezetet alakítja az edzések és versenyek alatt. A motivációs légkör formálja az egyének értelmezését, valamint válaszát a teljesítménnyel összefüggő tevékenységekkel kapcsolatban.” (Paic, 2019)

\section{CÉLKITUUZZÉS}

Kutatásunk célja egyrészt olyan korcsolyázók vizsgálata, akik felnőttként kezdtek el korcsolyázni tanulni, majd a sportot megszeretve versenycsapathoz csatlakoztak, és évente 2-3 versenyen vesznek részt.

Másrészt pedig az olyan felnőttek vizsgálata, akik korábban már korcsolyáztak, de valamilyen oknál fogva ez évekig abbamaradt, majd valamilyen indíttatás hatására újra elkezdtek foglalkozni komolyabban a korcsolyázással.

Vizsgálatunkban összehasonlítottuk azokat a felnőtteket, akik versenyeznek, azokkal a felnőttekkel, akik tanfolyami keretek között tanulnak korcsolyázni, mi a motivációjuk, miért kezdtek el korcsolyázni, miért pont ezt a szezonális sportágat választották.

Mi motiválta őket, hogy versenycsapatot alapítsanak, és versenyen induljanak el. A motiváció vizsgálata mellett a konfliktus kérdésköre is érdekelt minket. Versenyzőként minden évben találkoztunk konfliktushelyzetekkel, sokszor szem- és fültanúja is voltunk ezeknek.

Igazán érdekelt bennünket, hogy ezeknek a konfliktusoknak melyek voltak a kiváltó okai, és így mindig tudtam a kiváltó okot. Érdekelt azonban, hogy a felnőtteknél is ugyanazok a kiváltó okok a konfliktushelyzetekben, vagy az életkor és élettapasztalat előrehaladásával ezek megváltoznak?

\section{HIPOTÉZISEK}

A kutatás során a következő hipotéziseket fogalmaztuk meg:

H1: A szülők leggyakrabban gyermekeiket hozzák tanfolyamra, és ennek következtében állnak be ők is elsajátítani a korcsolyázás alapjait.

H2: A tanfolyamon szerzett rossz tapasztalat befolyásolja a felnőtteket a további edzéseken való részvételen, a versenyzőket azonban nem befolyásolja.

H3: Felnőttként nem fontos, hogy minden edzés alkalmával új lépést tanuljanak, de ha mégis, azt élvezettel teszik.

H4: A versenyző felnőttek több pénzt költenek a korcsolyázásra, mint a tanfolyamon részt vevő felnőttek.

H5: A versenyzőket más motiválja a fejlődés terén, mint a tanfolyamon részt vevő felnőtteket.

\section{VIZSGÁLATI ANYAG ÉS MÓDSZEREK}

Saját szerkesztésű, anonim kérdőívet készítettünk a tanfolyami résztvevóknek és a versenyzőknek is, amit 2020 áprilisában kezdtünk el kitöltetni. Mivel felnőttek voltak az érintettek, ezért beleegyező nyilatkozatra nem volt szükségem.

A személyes kitöltésre a koronavírus-járvány miatt nem volt lehetőségünk, ezért a gyorsabb terjeszthetőség miatt online felületen küldtük el az érintetteknek. A kitöltés során a koronavírus előtti időszakot kellett figyelembe venniük a kitöltőknek. Az egyesületekhez elektronikus levélváltásokat követően tudtuk eljuttatni a kérdőívünket, amelyet 104 fő küldött vissza. Szerencsére mindegyik edző partner volt benne, és nagyon segítókészek voltak a terjesztésben is. Azáltal, hogy csak a felnőttekre irányult a vizsgálatunk, kiestek azok a magyarországi klubok, amelyek nem foglalkoznak felnőtt versenycsapattal.

A felmérés során kvantitatív kutatási módszert alkalmaztunk. Összesen 46 kérdésre kellett választ adniuk a kitöltőknek. Az első 10 kérdésben demográfiai adatokra kellett válaszolniuk, amelyek között nyitott és zárt kérdések egyaránt szerepeltek. Az ezt követő 36 kérdésben a sportággal kapcsolatos kérdésekkel találkoztak a kitöltók. A választípusok között volt $3 \mathrm{db}$ : ahol nekik kellett beírniuk a válaszokat; $6 \mathrm{db}$ több válaszlehetőséget megjelölhető válasz, amelyet négyzettel jelölt az űrlap. $13 \mathrm{db}, 1-10$-ig terjedő Likert-skálás kérdés volt, amely attitűd vizsgálatra szolgált, a többi $24 \mathrm{db}$ kérdésre pedig egy válasz volt megjelölhető, amelyet az úrlap körrel jelölt.

A kérdőívre beérkezett válaszok feldolgozásánál a Microsoft Office Excel 2010-es verzióját használtuk, majd annak érdekében, hogy az SPSS statisztikai programot alkalmazni tudjuk, az Excel-táblázatban kiválasztottuk a megfelelő kérdéseket, majd átkódoltuk az adatokat. Az átláthatóság miatt egyes esetekben színes ábrákat is alkalmaztunk. 


\section{EREDMÉNYEK}

Első körben az alap demográfiai adatokat mutatjuk be. Jellemzően a csapatokat nők alkotják, ezért a kérdőív kitöltése során a demográfiai adatoknál arra számítottunk, hogy nagy többségben nőktől érkező válaszok lesznek. A számításaink be is igazolódtak, hiszen 87,5\% nő volt, vagyis 91 fó, és mindösszesen $12,5 \%$-uk volt csak férfi, vagyis 13 fó (1. ábra).

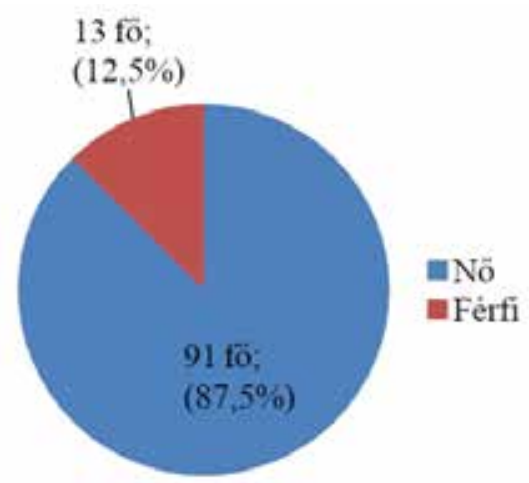

\section{1. ábra: Nők és férfiak megoszlásának} aránya. Ratio of women and men (\%). Forrás: Saját szerkesztés

$\mathrm{Az}$ életkor tekintetében nagyon szerteágazó válaszok érkeztek, és széles skálán mozogtak. 18 éves korú kitöltók voltak a legfiatalabbak (9 fó, 8,7\%). A legidősebb kitöltő 66 éves volt. Az átlagéletkor a 3039 év közöttiekből került ki, és a legtöbb válaszadó 40-49 év közötti volt. Ebból is látszik, hogy ahogyan Szemes, Harsányi és Tóth (2016) kutatásában említették, sosem késő elkezdeni sportolni, mert mindig tud élményt nyújtani, ezáltal pedig belsőleg motiválni az egyént.

A lakóhely vonatkozásában 49 fó a nagyvárost jelölte meg (47,1\%), 23 fő a fővárost (22,1\%), 20 fő a kisvárost (19,2\%), és a maradék 11 fó $(11,5 \%)$ a község és falu válaszokat adta meg. A legtöbb kitöltő nagyvárosban élők közül került ki.

Családi állapotuk: 38 fő házas (36,5\%); 25 fő párkapcsolatban él (24\%); 24 fó egyedülálló (23,1\%); 14 élettársi kapcsolatban él (13,5\%); és mindösszesen 3 fő elvált (2,9\%). A leggyakoribb a házas kitöltő. 60 személynek van gyermeke, míg 44 személynek nincsen gyermeke. Akiknek van gyermekük: 33,7\%-uknak 2 gyermeke van, ez 35 föt jelent; 14,4\%-nak 1 gyermeke van, ők 15 fót alkotnak; 8,7\%-nak 3 gyermeke van, ők 9 főt tesznek ki; 4 gyermeke pedig 1\%-nak van. 42,3\%-nak nincs gyermeke, ók 44 főt alkotnak.

Munkahelyre 48 fö (46,2\%); a 40, vagy annál több órát dolgoznak opciót választotta. Ezzel ők a leggyakoribb előfordulásúak. Akik 1-39 órát dolgoznak, ők 20 főt jelentenek (19,2\%). Megjelentek a válaszok között olyanok is, akik a munkanélküli opciót választották, 2 fő (1,9\%); és 1 fö nyugdíjasként jár korcsolyázni (1\%).
A demográfiai kérdések közül ezeket tartottuk fontosnak, illetve ezek között voltak számunkra érdekes válaszok, ezért említettük meg őket. A következőkben a sportággal, a motivációval és a konfliktussal kapcsolatos kérdések elemzését mutatjuk be. Elsőként arra kellett válaszolniuk, hogy milyen keretek között korcsolyáznak? Ebből kiderült, hogy 56 fő tanfolyami $(53,8 \%)$, míg 48 fő $(46,2 \%)$ versenyzői szinten korcsolyázik (2.ábra).

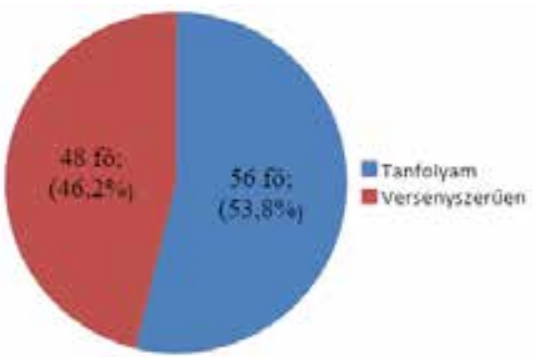

2. ábra: Milyen keretek között korcsolyáznak? In what kind of organization are you skating at?

Forrás: Saját szerkesztés

A következő kérdésben arra voltunk kíváncsiak, hogy akik versenyeznek, ők milyen szakágban sportolnak. Erre a többség, vagyis 46 fó $(44,2 \%)$ választotta a szinkronkorcsolyázást, 20 fó $(19,2 \%)$ a múkorcsolyázást, 2 fó a jégkorongozást (1,9\%).

Régen versenyzóként rengeteg költségünk volt, ezért kíváncsiak voltunk rá, hogy most ez hogy alakul, mennyit költenek a kitöltők arra, hogy sportoljanak. A legtöbben (76 fö; 73,1\%) a százezer forint alatti öszszeghatárt jelölték meg, egy szeptembertől márciusig tartó időszakban, ami a korcsolyázásban főszezonnak tekinthető. A legkevesebben: 2 fó $(1,9 \%)$ pedig egymillió forint feletti összeget írták.

Hogy kinek a hatására kezdett el korcsolyázni, a legtöbben azt válaszolták, hogy a család miatt választották ( 54 fó; $52 \%$ ), azonban sokan saját maguk miatt vágtak bele (22fö; 21\%). (3.ábra)

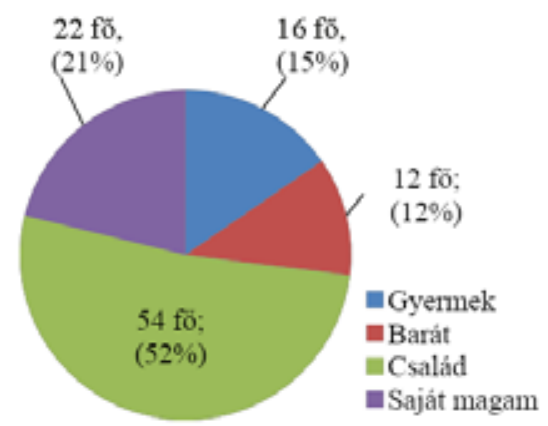

3. ábra: Ki miatt kezdett el korcsolyázni? Whose personal influence was the most significant when you decided to start skating? Forrás: Saját szerkesztés

Akik miatt elkezdtek korcsolyázni, a későbbiekben a többségüket (42 fö; 40,4\%) teljes mértékben motiválták, de akadt olyan is, akit egyáltalán nem (13fö; 12,5\%).
Ezzel szemben a saját motivációjukra vonatkozó kérdésre 75 -en (72,1\%), vagyis nagy többségben a 10-est jelölték meg a skálán, vagyis azt, hogy teljes mértékben saját motivációjuk, hogy sportoljanak. Egyvalakit pedig kevésbé befolyásol a saját motivációja (1\%).

Azt, hogy a támogatást kitôl és hogyan kapja meg az egyén, nagyban befolyásolja a késóbbiekben. Nem mindegy, hogy valaki csak szívesen jár edzésre, mert jó a társaság, és örömet okoz a mozgás, vagy az őt ért hatások teljesítményre buzdítják, és megpróbálja magából kihozni a legtöbbet ez által (Kun és Vincze, 2016).

Meglepő eredmény jött ki arra a kérdésre, hogy miért pont ezt a sportot választották. Többségében (42 fö; 40,4\%) azt a választ jelölték meg, hogy a média által értesültek róla. Ebbe beletartozott a tv és az internet is. Második népszerü válasz volt, hogy a család nagyban befolyásolta a választásukat (19fö; 18,3\%).

Annál a kérdésnél, hogy a légkör menynyire befolyásolja őket, meglepő válaszok érkeztek. Úgy gondoltam, hogy ez az egyik legmeghatározóbb tényező, azonban a kitöltők közül 52 főnek, vagyis csak 50\%-uknak fontos. Mindösszesen 1 fó, vagyis $1 \%$ mondta azt, hogy kevésbé meghatározó ez a tényező.

A kitöltőknek nagyon fontos, hogy minden alkalommal újat tanuljanak az edzés alkalmával (33fó; 31,7\%), ellenben 3 fónek $(2,9 \%)$ kevésbé fontos tényező. Viszont az esés vagy sérülés tekintetében pont az ellentettje figyelhető meg. Többséget ( 37 fö; $35,6 \%)$ kevésbé befolyásolja ez, és mindöszszesen csak 1 fö-t (1\%) befolyásol nagyon. Ezt az egyik kutató, Nagy is megemlíti könyvében, aki szerint a siker vagy a kudarc már az edzés során kialakul az egyénben. Az edző feladata, hogy ezeket helyesen kezelje, ha eredményt szeretne elérni (Nagy, 1973).

Mi motiválja óket a korcsolyázásra? A legmotiválóbb tényezőnek azt jelölték meg (38 fö; 36,5\%), hogy minél több korcsolyalépést tanuljanak meg. A második legmotiválóbb tényező, hogy jó hangulatban telnek az edzések (32 fó; 30,8\%), legkevésbé pedig a gyermek számít motiválónak (1f”; 1\%). (4.ábra)

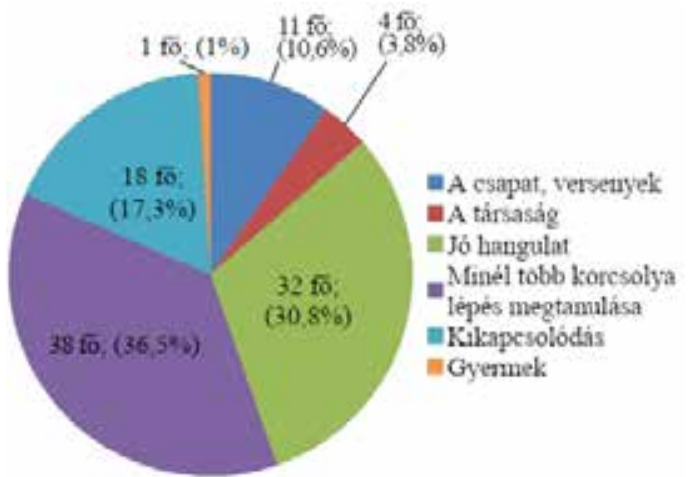

4. ábra: Mi motiválja a korcsolyázásra? Which factors motivates you to skate? Forrás: Saját szerkesztés 
$\mathrm{Az}$ edzői dicséret fontosságára 35 fő $(33,7 \%)$ válaszolta azt, hogy nagyon fontos, és mindösszesen 2 fő $(1,9 \%)$ válaszolta azt, hogy kevésbé fontos. Nagy szerint: „a sportoló magas szintű motiváltsága nagymértékben függ az edzőtől.” (Nagy, 1973)

Konfliktusban a válaszadók többségének nem volt része, ók 66 fót jelentenek (63,5\%); 38 fönek $(36,5 \%)$ pedig volt konfliktusa.

Ez valószínűleg azért alakulhatott így, mert az emberek többsége konfliktuskerülő. Akiknek konfliktusa volt, 24 fö; 23,1\%, ők legtöbb esetben a csapattársukkal, a nem megfelelő hangnem miatt konfrontálódtak (5. ábra). Ezeknek a konfliktusoknak a nagy része megoldódott (32 fó; 30,8\%), de akadt olyan is, ahol csak azért oldódott meg konfliktus, mert a személy felhagyott a korcsolyázással.

A konfliktusok megoldásához különböző kompetenciák szükségesek. Első körben fel kell ismerni, hogy mennyire vagyunk érintettek benne, ezt követően pedig el kell döntenünk, hogy azonnali megoldásra van szükség, vagy van egy kevés időnk kiválasztani a megfelelő konfliktuskezelő stratégiát (Németh, 2011; Németh 2015; Németh, 2016). A kérdőív válaszaiból az tükröződött, hogy nagy részben más személy bevonása nélkül oldódtak meg a kialakult konfliktushelyzetek.

$\mathrm{Az}$ interperszonális kapcsolatokban a konfliktusok kialakulása egy természetes folyamat, mert eleve magukban hordozzák ezeket (Németh, 2015). A másik konfliktust kiváltó ok az edzővel való nem egyetértésből származik ( 8 fö; 7,7\%). Szintén Németh említi, hogy nagyban befolyásolja a sportolók teljesítményét az edző-játékos közötti kapcsolat. Ez pozitív és negatív irányba is kihathat (Németh, 2017).

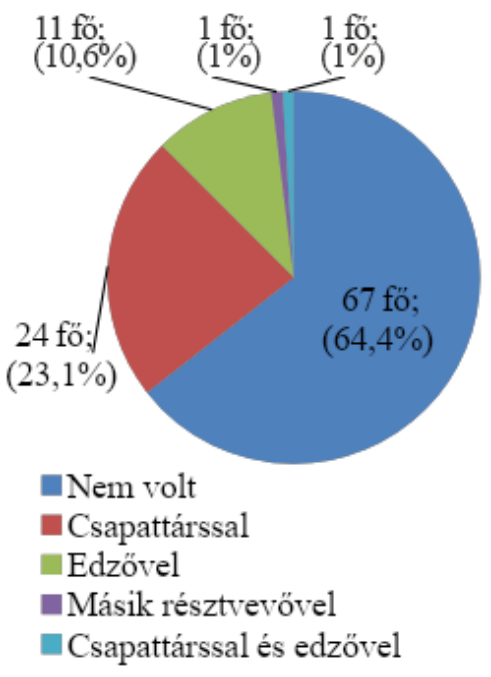

\section{5. ábra: Kivel volt konfliktusa? With whom you had a conflict? Forrás: Saját szerkesztés}

Mint ahogy feljebb említettem, természetes folyamat, ha egy csapatban összetüzés keletkezik. Ahhoz, hogy csapatként sikereket érjenek el, fejlődésre van szükség.
A hipotézisek vizsgálata során, az SPSS rendszerben a kereszttáblás vizsgálatra volt szükség, ezen belül is a Pearson korreláció segítségével kaptuk meg az eredményeket.

\section{7. ÖSSZEGZÉS}

Kutatásunk során öt hipotézisünk közül négy beigazolódott, egy pedig nem. Az elsőben azt feltételeztük, hogy a felnőttek leggyakrabban gyermekeiket hozzák tanfolyamra, és ennek következtében csatlakoznak a tanfolyami oktatáshoz. Ez az állítás nem igazolódott be, mert legtöbben a család (vagyis szülők és nagyszülők) befolyása miatt keresték fel az edzéseket, vagy saját maguk választották a sportot. Ennek a belső motivációnak köszönhető, hogy nagy kedvvel és odaadással járnak az edzésekre és versenyekre. Második hipotézisünkben azt állítottuk, hogy a tanfolyamon szerzett rossz tapasztalat befolyásolja a felnőtteket a további edzésen való részvételen, a versenyzőket azonban nem befolyásolja. Ez az állításunk beigazolódott, ami azt jelenti, hogy a versenyzők kedvét a rossz tapasztalatok kevésbé veszik el, mint az amatôr sportolókét. Ennek okát abban látjuk, hogy a negatív tapasztalatokat a magasabb szintű sportolók könnyebben fel tudják dolgozni. Ezekből levonják a következtetéseket, és a következó hasonló szituációkban már ennek megfelelően cselekednek. Harmadik hipotézisünkben azt állítottuk, hogy felnőttként nem fontos, hogy minden edzés alkalmával új korcsolyalépést tanuljanak, de ha mégis, azt élvezettel teszik. Ez a hipotézisünk is beigazolódott, amiből arra következtethetünk, hogy szeretik az új kihívásokat, de a régebben tanult technikai elemek gyakorlása is fontos számukra, ami a mozgások magabiztos végrehajtását eredményezi. Negyedik hipotézisünkben azt állítottuk, hogy a versenyző felnőttek több pénzt költenek a korcsolyázásra, mint a tanfolyamon részt vevő felnőttek. Ez az állításunk is beigazolódott, mert a versenyzóknek rengeteg pluszköltsége van (utazás, szállás, ruházat, tagdíj stb.), míg az amatőr sportolók legnagyobb kiadása a bérleti díjból származik. Az ötödik hipotézisünkben azt állítottuk, hogy a versenyzők és a tanfolyami keretek között sportolókat a fejlődés terén más motiválja. Ez a hipotézisünk is beigazolódott, ami azt jelenti, hogy a versenyszerü sportolók egyik legfontosabb célkitüzése, hogy folyamatosan fejlődhessenek, amelynek következményeként egyre jobb teljesítményt érhetnek el. Összességében megállapíthatjuk, hogy a korcsolyázás során nagyon fontos, hogy olyan pozitív motivációs környezetben fejlődjenek a sportolók, ahol a család és munka mellett kikapcsolódhatnak kortól, nemtől és a sportolói minősítésüktől függetlenül.

\section{IRODALOMJEGYZÉK}

Bíróné Nagy Edit (2011): Sportpedagógia. Dialóg-Campus Kiadó, Budapest - Pécs.

Gyömbér Noémi - Kovács Krisztina (2012): Fejben dől el. Noran Libro Kiadó, Budapest.
Kun Péter, Vincze Tamás (2016): Motiváció, teljesítményorientáció a sportban. Eszterházy Károly Főiskola tudományos közleményei (Új sorozat 43. köt). Tanulmányok a sporttudományok köréből. Sectio Sport. pp. 69-77. http:// publikacio.uni-eszterhazy.hu/id/eprint/1490 Letöltés: 2020.04 .01$.

Nagy György (1973): Sport és pszichológia. Alföldi Nyomda, Debrecen.

Németh Zsolt (2011): Az utánpótlásban dolgozó labdarúgó edzők konfliktuskezelő kultúrájának mintázata. Pécsi Tudományegyetem "Oktatás és Társadalom Neveléstudományi Doktori Iskola, Pécs.

Németh Zsolt (2015): A konfliktuspedagógia elméleti és gyakorlati háttere a testnevelő tanárok munkájában. PTE TTK Sporttudományi és Testnevelési Intézet, Pécs. http://tamop-sport. ttk.pte.hu/files/tananyagfejlesztes/a-konfliktuspedagogia-elmeleti-es-gyakorlati-hattere-a-testnevelotanarok-munkajaban.pdf Letöltés: 2020.04.19.

Németh Zsolt (2016): Testnevelő tanárok konfliktuskezelő stratégiáinak fókuszcsoportos vizsgálata. Magyar Sporttudományi Szemle 17. évfolyam, 2. szám, 48-49.

Németh Zsolt (2017): Konfliktuskezelő stratégiák a labdarúgó edző- játékos- szülők közötti interakciókban. Testnevelés, Sport, Tudomány, 2. évfolyam 4. szám, 55-81. http://real.mtak. hu/90200/1/06_N\%C3\%A9meth.pdf Letöltés: 2020.04.11. DOI: 10.21846/TST.2017.4.5

Szemes Ágnes, Harsányi Szabolcs Gergö, Tóth László (2016): Különböző sportágakban versenyző sportolók sportmotivációjának és flowélményének összehasonlító vizsgálata. Testnevelés, Sport, Tudomány, 1. évfolyam 1. szám 80-90. http://real.mtak.hu/40248/ Letöltés: 2020.03.05. DOI: 10.21846/TST.2016.1.8

Paic Róbert (2019): A sportoló-edző kapcsolat, a motiváció és az észlelt motivációs környezet összefüggéseinek vizsgálata a férfi kézilabdázásban. Doktori értekezés, PTE BTK, Neveléstudományi Doktori Iskola, Pécs. https:// pea.lib.pte.hu/bitstream/handle/pea/19318/ paic-robert-tezis-hun 2019.pdf?sequence=2\&isAllowed=y Letöltés: 2020.04.13

Pelletier, L. G., Fortier, M. S., Vallerand, R. J., Tuson, K. M., Brière, N. M., \& Blais, M. R. (1995): Toward a new measure of intrinsic motivation, ext-rinsic motivation, and amotivation in sports: the Sport Motivation Scale (SMS). Journal of Sport and Exercise Psychology, 17, 35-53. https://www.researchgate.net/ publication/266178539_Toward_a_New_Measure_of_Intrinsic_Motivation_Extrinsic_Motivation_and_Amotivation_in_Sports_The_Sport Motivation_Scale_SMS Letöltés: 2020.04. 15. DOI: 10.1123/jsep.17.1.35

Ryan, R. M. and Deci, E. L. (2000a): Self-determination theory and the facilitation of intinsic motivation, social development, and well being. American psychologist, 55. 68-78. https://selfdeterminationtheory.org/SDT/documents/2000_ RyanDeci_SDT.pdf Letöltés: 2020.04.21

Ryan, R. M. and Deci, E. L. (2000b): Intrinsic and Extrinsic Motivations: Classic Definitions and New Directions. Contemporary Educational Psychology25,54-67. https://www.sciencedirect. com/science/article/pii/S0361476X99910202?via\%3Dihub Letöltés: 2020. 04.15. DOI: 10.1006/ ceps.1999.1020 